Collins, E. Treacher-Case Report. Trans. Ophthal. Soc. U.K., Vol. XII, 1892.

Shine, F. W.-New York Eye and Ear Infirmary Clinical Reports. Vol. I, p. 31. 1930.

Callender, G. R.-A study of histology in 111 cases of Melanotic Tumours of the Eye. Trans. Amer. Acad. of Ophthal. and Otolaryng. p. 31. 1931.

Samuels, B.-Anatomic and Clinical Manifestations of Necrosis in 84 cases of Sarcoma of the Choroid. Arch of Ophthal., Vol. II, p. 998.1934.

Verhoefr, F. H.-Hæmorrhage in blind eyes. Trans. Amer. Ophthal. Soc., Vol. XXX, p. 100.1932 ,

HULKE, J. W.-Intra-ocular Ossification. Med. Times and Gaz., 1857.

Morax, V.-Cancer de l'appariel visuel, p. 222. 1926.

\title{
PATHOLOGICAL CLASSIFICATION OF THE CHOROIDAL SARCOMATA
}

Although the pigmented malignant tumours of the choroid are commonly known as sarcomata, much doubt exists, especially among pathologists, as to the origin of these tumours. Are they derived from mesoblastic or epiblastic tissue?

Before commencing on a discussion of this kind, it is necessary to understand the origin of the pigment melanin, as far as is known.

Formerly it was thought that melanin was a derivative from the blood pigment haematin, but this has now been shown to be untrue, since melanin contains no iron. Moreover, the pigment is observed in frog embryos where blood is not present, and it is now generally accepted that it is a product of the metabolic activity of the cell protein.

It was suggested that melanin was an oxidation product from a colourless precursor and that the oxidation was activated by a ferment.

Bloch isolated from the embryo of the broad bean $3: 4$ dihydroxyphenylalalin, which, for the sake of brevity, he called "dopa."

This " dopa" substance was seen to be readily changed to melanin by a ferment or oxidase present in the cells of pigmented tissues. When the "dopa " was added to epidermal cells of the skin in frozen formalin fixed sections, melanin granules appeared; and it was assumed that these cells of the epidermis, in which the pigment appeared, contained the ferment or dopa-oxidase which converted the " dopa" into melanin.

It was noticed also that this reaction was much-stronger in tissues which had been irradiated by radium or X-rays, and that it was not present in scars and in albinos.

It will be readily realised how important this discovery was, for it made it possible, by staining sections from embryos, to foretell the exact cells of the germinal layer which later were to give rise to melanin. 
In the human skin, those cells in which granules of melanin occur, when stained with the "dopa," are called melanoblasts, and are epithelial in origin; the epithelial origin of melanin is seen also in the columnar epithelium lining the ink sac of Sepia, and the pigmented cells of the epidermis may be observed passing into the deeper layers of the dermis in the tree frog.

The whole problem of the correct classification, as sarcomata or carcinomata, of the pigmented intra-ocular neoplasms rests on the origin of the melanoblast within the globe.

The melanoblast of the skin may be solely derived from epithelial tissue, but a somewhat different state of affairs exists within the globe.

Various possibilities present themselves with regard to the origin of the melanoblasts of the uveal tract. These will now be discussed together with the evidence, if any, for and against the different views.

Mesoblastic origin.-The view held by some authorities that the pigment cell is purely mesoblastic in origin, and that the pigment in the retinal epithelium (ectodermal) has diffused into these cells from the choroid, does not seem to be correct.

Embryologically, the pigmented cells of the outer layer of the secondary optic vesicle, which is derived from neural epiblast, make their appearance about the fifth week of intra-uterine life in the human foetus, and the melanin within these cells is in the form of rod-shaped granules.

The earliest stage at which the pigment is observed in the choroid is at the end of the fifth month, and generally not before the = seventh month of intra-uterine life, the pigment in these cells is, moreover, in the form of small granules and never occurs in the form of rod granules.

These facts in themselves make it impossible for the pigment in the retinal epithelium to have diffused from the choroidal cells before the latter cells have developed any pigment.

Epiblastic origin.-The adherents to this view maintain that all the melanoblasts are epiblastic in origin, and that the pigment found in the choroidal cells has diffused from the pigmented retinal epithelial cell into the choroid.

Taking the " developmental-time". factor into consideration, this hypothesis is possible for, as already stated, the pigment in the retinal cells is present some months before it is observed in the choroid.

But, very soon after the formation of the secondary optic vesicle, however, and long before pigment is observed in the choraid, the outer layers of the vesicle become reduced to a single layer of cells,' which produce on their outer side the membrane of Bruch. No pigment cells, either in the embryo or in later life have been 
observed to traverse this membrane; moreover according to Ida Mann the pigment, when first seen in the choroid, is in the vicinity of the blood vessels in the external part of the choroid and not next to the membrane of Bruch, as would be expected if the pigment had diffused from the retinal pigmented epithelium through this barrier into the choroid.

Mesoblastic and epiblastic origin.-Those that hold this view maintain that the melanoblast within the globe at all events, may be derived from both mesoblastic and epiblastic tissue.

Against this theory Dawson stated "That cells definitely derived from mesoderm can form melanin pigment has not been demonstrated, so long as no malignant change has set in."

Treacher Collins disagrees, however, with this statement and the evidence given by him for a mesodermal origin of the melanoblast is so conclusive that I have quoted him verbatim.

" In connection with congenital malformations of the tissues of the eye, however; we have evidence which seems to prove definitely the generation of melanin pigment by mesoblastic cells.

"There can be no doubt that the lamina irido-pupillaris, which develops before the ingrowth of the secondary optic vesicle between the cornea and lens, is mesoblastic in origin. Normally its pupillary portion entirely disappears before birth and in the blonde races it is never pigmented. Occasionally, as an abnormality, portions of it persist throughout life ; these persistent remnants may then. like the stroma of the iris, become pigmented. Usually these persistent remnants, though they extend into the pupillary area, remain attached to the anterior surface of the iris. Sometimes, however, remnants of the membrane are met with attached to the anterior surface of the lens or the posterior surface of the cornea, without any iritic attachment; these also may becom: pigmented. Into such isolated pieces of mesoblastic tissue, adherent to avascular and unpigmented structures, it is most improbable that there can be any migration of pigmented epiblastic cells; nor are there any lymphatic channels leading to them by which melanin granules could be conveyed. It would seem, therefore, that the formation of pigment in these remnants of pupillary membrane must be due to some inherent capacity of the mesoblastic cells of which they are composed.

"In cases of congenital anophthalmia, in which the primary optic vesicle has failed to bud out from the anterior encephalic vesicle, or where for some other reason the neural epiblastic tissue has failed to extend into the orbit, nodules are sometimes found in the orbit to which the orbital muscles are attached, which are composed of the mesoblastic tissues of the eye, the sclerotic and choroid. The cells of the choroidal tissue are pigmented, containing granules of melanin which, must have been generated by the mesoblastic cells." 
Personally I favour the view that the pigmented cells within the globe are derivatives from both the epiblastic and mesoblastic layers.

The early existence of the membrane of Bruch and the position of the first observed pigment in the choroid, in my opinion, upsets the theory that the choroidal pigment is retinal in origin, and the " developmental-time" factor disproves the theory of the retinal pigment diffusing from the choroid.

In conclusion, I consider the malignant melanomata to be mesodermal in origin, and therefore true sarcomata, for the following reasons :-

1. The choroidal melanoblast is derived from mesoderm.

2. The tumours behave clinically as sarcomata, spreading by the blood stream, and usually forming their first deposits in the liver.

3. Lymphatic channels and glands are seldom, if ever, involved. (Deposits in the cervical glands have been reported in one case of sarcoma of the choroid by Terry and Johns.)

4. The membrane of Bruch is often found intact over the tumour.

\section{PROGNOSIS}

Statistics may be misleading and should only be used as a guide and help on which to base one's statements.

In all comparative statistical work, it is of the utmost importance to employ exactly the same methods in constructing each tabular statement, in order that comparisons may be a true guide to the conclusions arrived at.

It has been impossible to verify the clinical history of more than one hundred and sixty-three cases out of the two hundred and sixty-three, and some of these are incomplete in their clinical history in so far as they have not been followed for more than three years subsequent to operation; these cases have, of course, been eliminated in the appropriate tables.

Of this total of one hundred and sixty-three cases, it is known that eighty-six are dead and seventy-seven alive.

The cause of death in those patients dying has been ascertained either from personal communication with the medical attendant at their last illness; or from copies of the death certificates from the Registrar General's office at Somerset House.

As post-mortem examinations were carriéd out in very few cases, the cause of death as-stated by the medical attendant or on the death certificate has been assumed to be correct, except in those 
cases in which death was said to have occurfed from such conditions as cancer of the liver, cirrhosis of the liver with ascites, and cancer of the stomach or small intestine, where I have assumed the patient died from sarcoma.

Patients dying from intercurrent disease, and those who are known to be dead, the cause of death being uncertain, have been treated separately in the statistical tables.

It is commonly believed that, if patients live for more than three years after operation, their chance of survival is good.

Frudenthal stated in 1891, "If after three or four years from the time of operation there is no sign of recurrence, we may with considerable confidence, though not with absolute certainty, regard the cure as final."

It is, I think, unwise to talk of cure in any variety of malignant disease, if we understand by a cure security from the re-appearance of the growth, either locally or metastatically, and in the following tables I have attempted to show the relative mortality rate within three, five and ten years from operation, and to set forth reasonable deductions from these figures.

Of the one hundred and sixty-three cases, twenty-eight occurred in the years 1936 to 1939 inclusive, nine in the years 1934 to 1935 inclusive, and fifty-nine in the years 1929 to 1933 inclusive.

In constructing each table it is, of course, necessary to eliminate cases which occur within the three, five and ten year intervals respectively of the date of this paper. If, for instance, in considering a three year survival rate any cases occurring within the last three years are included, an accurate result would not be obtained, because no one is yet in a position to say whether any of these cases will die within three years or live for more than three years.

Those cases dying from intercurrent disease and those which have died, the cause of death being unascertained within three, five and ten years from operation, must also be eliminated in the appropriate tables, for if one included in the five-year mortality table a case which had died within five years of operation from arterio-sclerosis, the result would again be inaccurate, as no one can say whether, but for the intervention of this extraneous factor, death would or would not have occurred within five years of operation from sarcoma.

Three year mortality ratc.-From Table 1 it is seen that thirtyfour cases, or 27.9 per cent., died from sarcoma within three years of operation ; of the eighty-eight cases, or 72.1 per cent. who were alive, a further twenty-one cases, or $17 \cdot 2$ per cent., died subsequently from sarcoma, and therefore a three-year period of survival cannot be regarded as anything approaching a so-called "cure." 
Survival and Mortality Rates-All Cases.

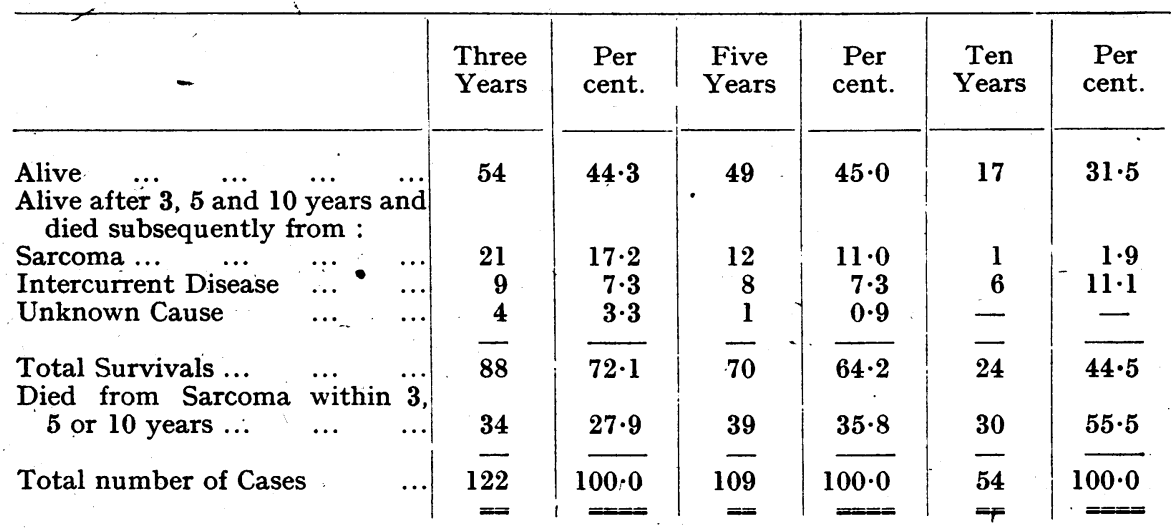

Five-year mortality rate.-The number of cases dying from sarcoma within five years of operation is thirty-nine or 35.8 per cent.; of the seventy cases, or 64.2 per cent., that were alive, a further twelve cases, or 11 per cent., died subsequently from sarcoma. It does not appear, therefore, that a five-year period of survival is long enough to pronounce the case " cured."

Ten-year mortality rate.-The number of cases dying within ten years of operation is thirty, or 55.5 per cent.; of the twentyfour, or 44.5 per cent., that were living, only one, or 1.9 per cent., has subsequently died from sarcoma, and of the remaining twenty-three, seventeen are still alive, and six died from intercurrent disease.

It appears, therefore, that if a patient lives ten years after operation, the chance of death occurring from sarcoma is small, and the case can probably be called a cure.

It must be borne in mind, however, that the number of cases (fifty-four) considered for more than ten years is relatively small, and a later investigation into the subsequent history of cases now exclusively confined to the three and five year mortality tables would give more accurate statistics, being based on a larger number of casess.

It would be extremely helpful in an investigation of this sort, if the various ophthalmic hospital's records on intra-ocular sarcoma were more carefully kept, with a view to recording all details of the subsequent history of these patients, especially the date and cause of death.

In addition to those known deaths from sarcoma, I have records of eight, eleven and twelve deaths in the three, five and ten year periods respectively, the cause of death being uncertain. The mortality rates in the tables must therefore be taken as minima, 


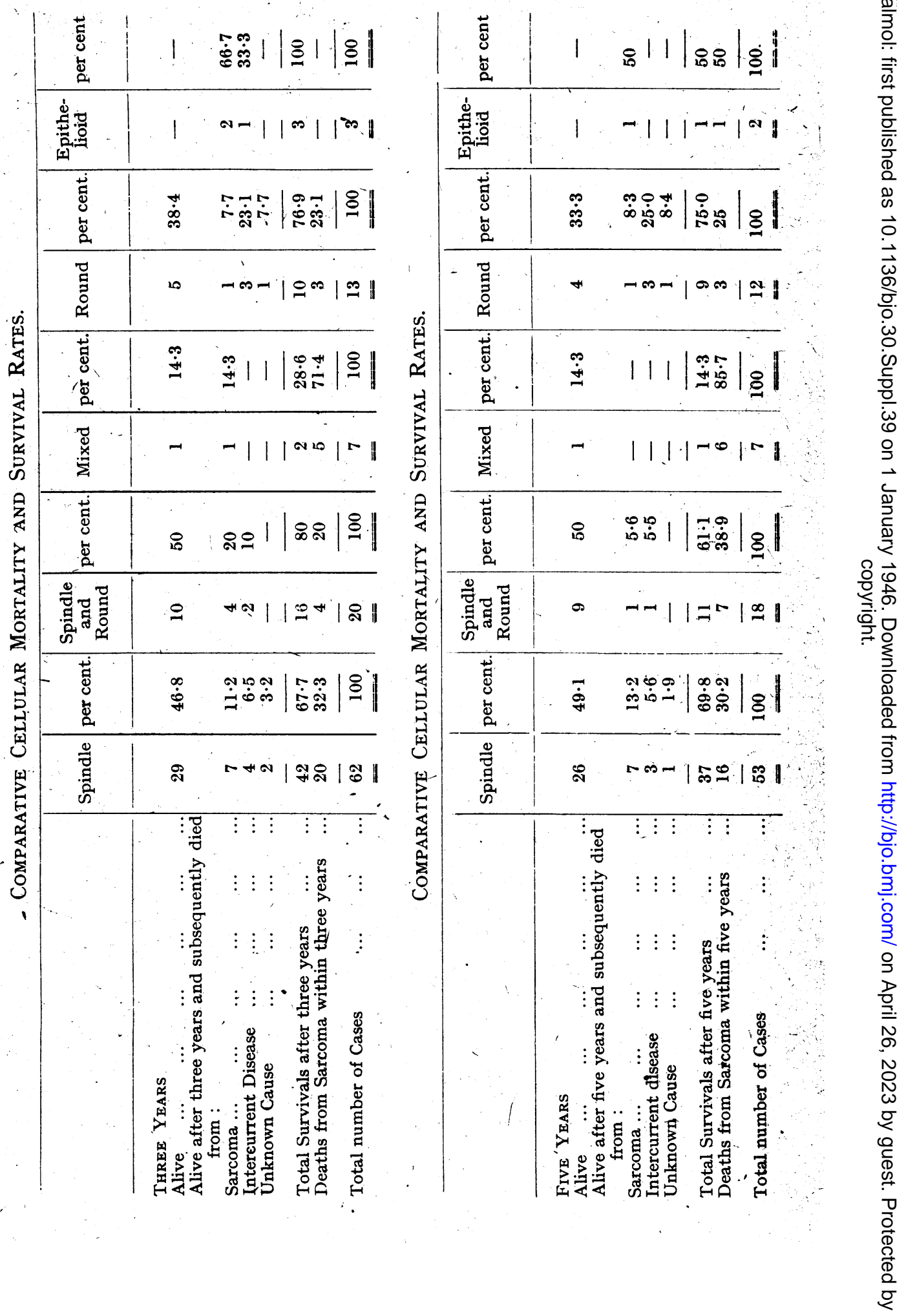


for even if half of these deaths were due to sarcoma, the mortality percentage is increased to 30 per cent. for the three, 40 per cent. for the five and 60 per cent. for the ten year periods.

Comparative Cellular Mortality and Survival Rates.-Out of the two hundred and sixty-three cases, the cellular content is unknown in thirty-eight; the remaining two hundred and twentyfive were :-

$$
\begin{array}{lllllr}
\text { 1. } & \text { Spindle } & \ldots & \ldots & \ldots & 140 \\
\text { 2. } & \text { Round } & \ldots & \ldots & \ldots & 35 \\
\text { 3. } & \text { Spindle and } & \text { Round } & \ldots & \ldots & 28 \\
\text { 4. } & \text { Epithelioid } & \ldots & \ldots & \ldots & 6 \\
\text { 5. } & \text { Mixed } \ldots & \ldots & \ldots & \ldots & 16
\end{array}
$$

The comparative mortality rate for each type of cell is found by constructing tables by exactly the same methods as those used in constructing the three, five and ten year mortality and survival rate tables, that is, eliminating :-

1. Cases whose subsequent history is unknown.

2. Cases occurring within three or five years, previous to the date of writing.

3. Cases of death occurring from uncertain causes, or from intercurrent diseases within three and five years of operation.

From the tables it appears that the mixed cell growth is by far the most malignant variety. Of the seven cases in the three year and five year tables, five, or 71.4 per cent., died from sarcoma within three years, and six, or 85.7 per cent. died within five years from operation, compared with the general mortality rates of $\mathbf{2 7 . 9}$ per cent. and 35.8 per cent. for the three and five year periods respectively.

Apart from the spindle cell, the statistics cover so few cases that they cannot be regarded as trustworthy, but it appears very evident from them that the mixed cell is the most malignant.

Extra-ocular involvement and prognosis.-Twenty-nine cases of extra-ocular growth occurred in the whole series. The subsequent history of eleven cases is unknown and of the remaining eighteen, two are recent cases, and two more died from intercurrent disease within three years of operation : these have been excluded from the following table.

From this table it is evident that the prognosis of cases showing extra-ocular spread is comparatively bad, 50 per cent. dying within three years, compared with 27.9 per cent. for the general mortality rate for all cases for three years, and 69.2 per cent. dying within five years, as compared with 35.8 per cent. for the general mortality rate for all cases for five years. 
Survival ANd Mortality Rates for CASEs with Extra-ocular INVOLVEMENT.

\begin{tabular}{|c|c|c|c|c|}
\hline & $\begin{array}{l}\text { Three } \\
\text { Years }\end{array}$ & $\begin{array}{l}\text { Per } \\
\text { cent. }\end{array}$ & $\begin{array}{l}\text { Five } \\
\text { Years }\end{array}$ & $\begin{array}{l}\text { Per } \\
\text { cent. }\end{array}$ \\
\hline $\begin{array}{l}\text { Alive } \quad \ldots \quad \ldots \quad \ldots \\
\text { Alive after } 3 \text { or } 5 \text { years, subsequently } \\
\text { dying from : }\end{array}$ & 1 & $7 \cdot 1$ & 1 & $7 \cdot 7$ \\
\hline $\begin{array}{lllll}\text { Sarcoma } & \ldots & \ldots & \ldots & \ldots\end{array}$ & 5 & $35 \cdot 8$ & 3 & $23 \cdot 1$ \\
\hline $\begin{array}{llll}\text { Intercurrent Disease } & \ldots & \ldots \\
\text { Unknown Cause } & \ldots & \ldots & \ldots\end{array}$ & 1 & $\stackrel{7 \cdot 1}{-}$ & 二 & 二 \\
\hline $\begin{array}{l}\text { Total Survivals } \ldots \\
\text { Died within } 3 \text { or } 5 \text { years from Sarcoma }\end{array}$ & 7 & $\begin{array}{l}50 \cdot 0 \\
50 \cdot 0\end{array}$ & $\begin{array}{l}\mathbf{4} \\
\mathbf{9}\end{array}$ & $\begin{array}{l}30 \cdot 8 \\
69 \cdot 2\end{array}$ \\
\hline Total number of Cases & 14 & $100 \cdot 0$ & 13 & $100 \cdot 0$ \\
\hline
\end{tabular}

Subsequent deaths from Sarcoma occurred as follows :1 within seven years.

1 within ten years.

1 within fourteen years.

Moreover, of the four survivals after five years, three died from sarcoma. within seven, ten and fourteen years respectively, the present survivor having lived eleven years since operation.

Prognosis of cases with malignant cells present in the emissaria of the globe.-Twelve cases were found in the present series which showed malignant cells in the anterior ciliary, vortex, or posterior ciliary veins.

Of this number of cases seven are alive (five after five years), two are recent cases and five cases are dead.

Of the five cases that showed malignant cells in the venae vorticosae, four are alive after four, eight, eleven and thirteen $y$ ears, contrasting markedly with the mortality rates for cases with extra-ocular extension of the growth. Yet one would have thought that once malignant cells were present in the great venous outlets from the globe, metastases would certainly be present as early as in cases with extra-ocular involvement by the growth.

The percentage of survivals after five years in these cases is 50 per cent. (excluding the two recent cases), the percentage of survival of cases after five years showing extra-ocular spread being 31 per cent.

It does not appear, therefore, that malignant cells in the venous outlets from the globe are necessarily of bad prognostic import.

Prognosis of cases with involvement of opic nerve by growth.There are twenty-four cases of optic nerve involvement, of which the subsequent history of eleven cases is unknown. Two of the remaining thirteen are recent cases and have been excluded from the statistical table. 
Three year Mortality and Survival Rates

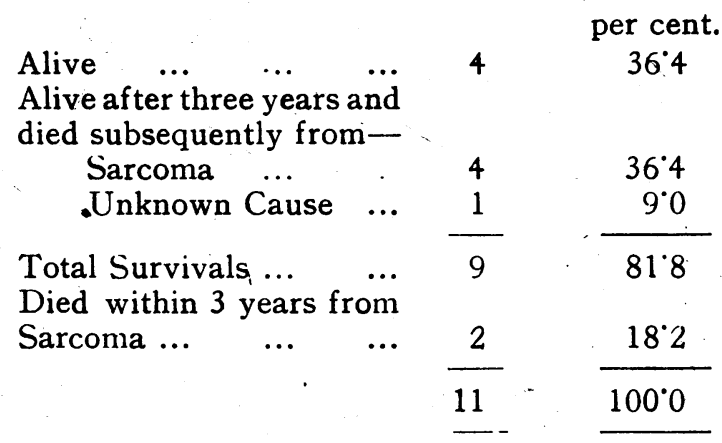

It is interesting to note that both cases dying within three years of operation had extra-ocular extension of the growth, and this factor probably caused their early death.

Of the four that died from sarcoma after three years, one died within five, two within seven and one within ten years.

Two of the cases that are alive have lived for twelve and thirteen years, respectively. It does not appear therefore that involvement of the optic nerve by growth is a bad prognostic sign, nor have I any evidence to show that intra-cranial extension of the growth occurs in cases in which the nerve is involved by sarcoma cells.

Age and prognosis.- It was thought advisable to investigate the survival and mortality rates of these cases of sarcoma in relation to the age of the patients.

The ages of the patients were grouped into three sections, 0 -thirty years, thirty-one to fifty years, and fifty-one years and onwards.

Survival and Mortality Rates for Age Groups. Five Years.

\begin{tabular}{|c|c|c|c|c|c|c|}
\hline 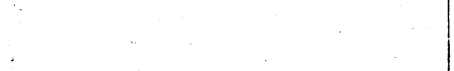 & \multicolumn{2}{|c|}{$\begin{array}{l}\text { 0-30 Years } \\
\text { per cent. }\end{array}$} & \multicolumn{2}{|c|}{$\begin{array}{l}\text { 31-50 Years } \\
\text { per cent. }\end{array}$} & \multicolumn{2}{|c|}{$\begin{array}{c}51 \text { Years and Over } \\
\text { per cent. }\end{array}$} \\
\hline $\begin{array}{l}\text { Alive } \quad \ldots \quad \ldots \quad \therefore \\
\text { Survived after five years and sub- } \\
\text { sequently died from : }\end{array}$ & 3 & $75 \cdot 0$ & 24 & $57 \cdot 1$ & $19^{-}$ & $33 \cdot 9$ \\
\hline $\begin{array}{lllll}\text { Sarcoma } & \ldots & \ldots & \ldots & \ldots\end{array}$ & - & - & .5 & $12 \cdot 0$ & 6 & $10 \cdot 7$ \\
\hline Intercurrent Disease & 1 & $25 \cdot 0$ & 3 & $7 \cdot 1$ & $\mathbf{3}$ & $5 \cdot 4$ \\
\hline $\begin{array}{llll}\text { Unknown Cause } & \ldots & \ldots & \ldots\end{array}$ & - & 一. & - & - & 1 & $1 \cdot 8$ \\
\hline $\begin{array}{l}\text { Total Survivals after five years } \\
\text { Died from Sarcoma within five }\end{array}$ & 4 & $100 \cdot 0$ & 32 & $76 \cdot 2$ & 29 & $51 \cdot 8$ \\
\hline years $, \cdots, \quad \cdots \quad \ldots, \quad \cdots$ & - & - & 10 & $23 \cdot 8$ & 27 & $48 \cdot 2$ \\
\hline Total Cases... $\quad \ldots \quad \ldots$ & $\begin{array}{l}4 \\
==\end{array}$ & $100 \cdot 0$ & $\overline{42}$ & $100 \cdot 0$ & $\overline{56}$ & $100 \cdot 0$ \\
\hline
\end{tabular}


Survival and Mortality Rates for Age Groups. THREE YeARS.

\begin{tabular}{|c|c|c|c|c|c|c|}
\hline \multirow{2}{*}{ 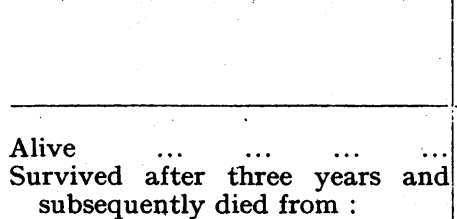 } & \multicolumn{2}{|c|}{$\begin{array}{c}0-30 \text { Years } \\
\text { per cent. }\end{array}$} & \multicolumn{2}{|c|}{$\begin{array}{l}\text { 31-50 Years } \\
\text { per cent. }\end{array}$} & \multicolumn{2}{|c|}{$\begin{array}{l}51 \text { Years and Ove } \\
\text { per cent. }\end{array}$} \\
\hline & 3 & $75 \cdot 0$ & 26 & $8 \cdot 5$ & 22 & $34 \cdot 9$ \\
\hline $\begin{array}{lllll}\text { Sarcoma } & \ldots & \ldots & \ldots & \ldots\end{array}$ & - & - & 7 & $15 \cdot 2$ & 11 & $17 \cdot 4$ \\
\hline rent Disease & 1 & $25 \cdot 0$ & 3 & & 4 & $\begin{array}{l}6 \\
3\end{array}$ \\
\hline $\begin{array}{llll}\text { Unknown Cause } & \cdots & \cdots & \cdots\end{array}$ & 二 & & & & 2 & \\
\hline $\begin{array}{l}\text { Total survivals after three years } \\
\text { Died within three years from sar- }\end{array}$ & 4 & $100 \cdot 0$ & 37 & $80 \cdot 4$ & 39 & $61 \cdot 9$ \\
\hline $\begin{array}{lllll}\text { coma } & \ldots & \ldots & \ldots & \ldots\end{array}$ & - & - & 9 & $19 \cdot 6$. & 24 & $38 \cdot 1$ \\
\hline Total Cases... & $\begin{array}{r}4 \\
==\end{array}$ & $100 \cdot 0$ & 46 & $100 \cdot 0$ & $\underline{63}$ & $100 \cdot 0$ \\
\hline
\end{tabular}

From the three year table it will be seen that none of the four cases under thirty years of age died within three years, nine, or 19.6 per cent., of the forty-six cases in the thirty-one to fifty year age group died within three years, and that twenty-four, or 38.1 per cent., of the sixty-three cases in the fifty-one years and onward group died within the three years.

From the five year table we see that the four patients under thirty years of age are all still living, that ten, or 23.8 per cent., of the forty-two cases in the thirty-one to fifty year group died from sarcoma, and that twenty-seven, or 48.2 per cent., of the fifty-six cases in the fifty-one years and onward group died.

From these figures it appears that cases under the age of thirty; show a better prognosis than the older patients.

\section{PROGNOSTIC SIGNIFICANCE OF RETICULIN}

In 1935, Callander and. Wilder published an interesting paper on the prognostic significance of reticulin, or argyrophil fibres, in choroidal sarcomata.

They studied two hundred and five cases of choroidal sarcomata, following forty-six cases for five years or longer, and found that there was an apparent connection between the reticulin content of the growth and the prognosis.

I have attempted to confirm their research work, but two difficulties were encountered. First, there was a scarcity of cases which had been followed for five years or more, in which the pathological material was available for the special staining methods 
employed, and secondly there were certain disadvantages of working with, in some cases, extremely old material.

All connective tissue, whether occurring in normal, inflammatory or neoplastic tissues, contains in addition to the cellular elements, an intercellular structureless ground substance, in which three types of fibres are observed, collagen, reticulin and elastin.

Collagen fibres.-These are the most abundant fibrils seen in connective tissue. They are easily stained with connective tissue stains, but are not able to be impregnated with silver salts.

Elastin fibres.-These are seen as fibres or flat ribbons, and can be demonstrated with special elastic tissue stains. Silver salts do not impregnate them.

Reticulin fibres. - These differ from collagen and elastin fibres in that they are demonstrated badly, or not at all, with ordinary stains, but can be strikingly demonstrated by impregnating them with silver salts, and for this reason they are sometimes called argyrophil fibres.

Callender and Wilder observed that the fibre distribution varied in marked degrees in different tumours, and in different areas of the same tumour, and the present work agrees with this, every gradation from absence to a complete fibrillar network being noticed. These two workers classified their tumours into three groups :-

Group 1: Tumours containing no reticulin.

Group 2. Tumours containing areas with and without reticulin fibres.

Group 3. Tumours having rețiculin fibres throughout the whole of their substance.

Forty-six cases of choroidal sarcomata were classified into the above three groups and followed for five years or more, the results were as follows :-

Group 1. Three cases, all of which died.

Group 2. Thirty-eight cases, of which twenty-six or 68.4 per cent. died within five years.

Group 3. Five cases, all of which were living for five years.

In the present work, twenty-four cases of sarcoma were stained by the silver impregnation method and the reticulin content investigated; of these cases, nine are dead and fifteen are living.

Of the total of twenty-four cases, numbers nine, eleven and seventeen to twenty-four inclusive, could not be followed for five years, or were of comparatively recent origin, leaving fourteen 


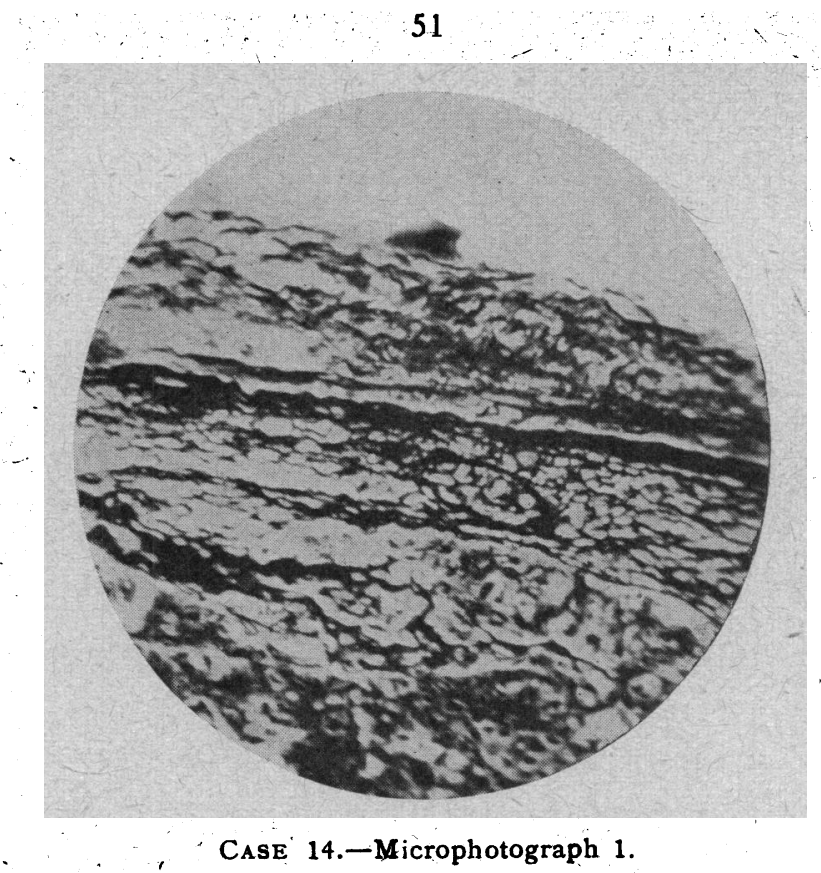

Illustrates barrier of reticulin fibres on retinal surface of growth. This barrier surrounded the whole circumference of the grówth.

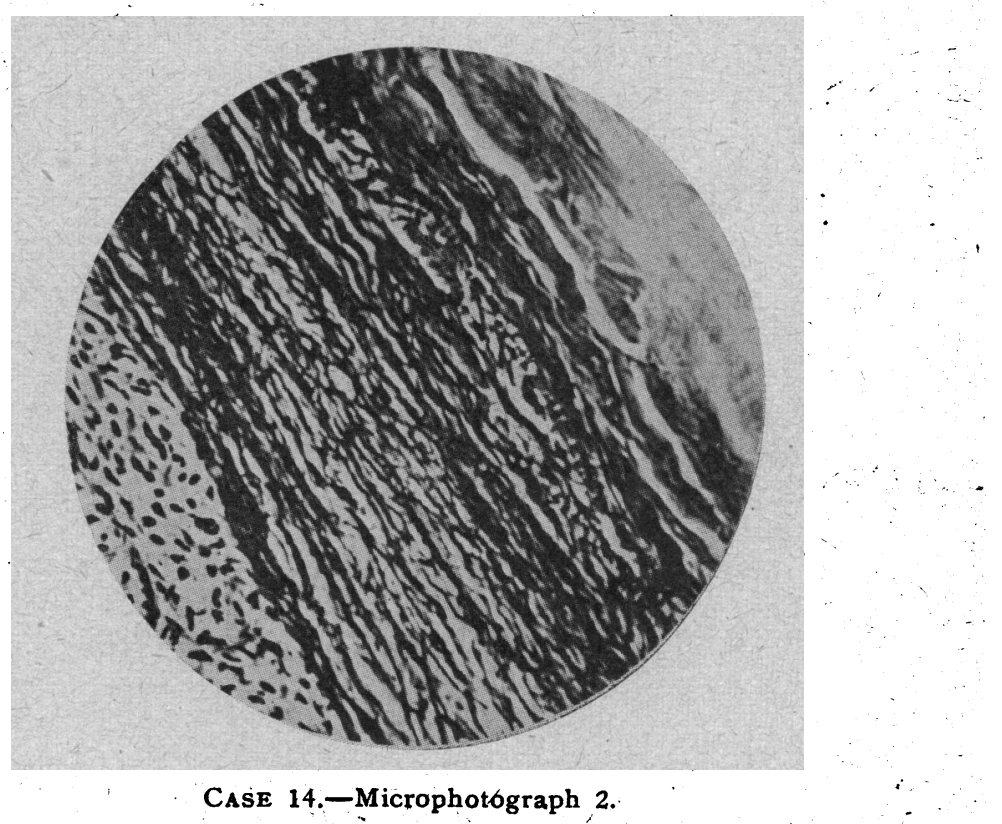

Illustrates reticulin barrier surrounding the growth on its scleral surface. 
cases where the results can be compared with those of Callender and Wilder.

These cases have been divided into the three "Callender and Wilder Groups."

Group 1. Four cases.-Two, numbers seven and eight died within five years, and two, numbers nine and fourteen survived for more than five years, one of these, number nine dying within six years from sarcoma, and the other number fourteen, being alive after eight years. Case number fourteen is interesting in that reticulin in the main part of the growth is entirely absent, but a barrier of fibres was seen surrounding the growth, both on its external c: scleral surface, as well as on its retinal surface. A microphotograph illustrates this.

Group 2. Eight cases.-Five, numbers two, three, four, five and six died within five years, and three, numbers one, fifteen and sixteen survived after this time; of the survivors, one, number one, died within six years and the remaining two, numbers fifteen and sixteen are still alive after seven and five years respectively. Both these cases, numbers fifteen and sixteen, had very little reticulin within the growth, but showed well formed surrounding capsules of reticulin, as in the case fourteen, of Group 1.

Group 3. Three cases.-Numbers ten, twelve and thirteen are all alive after five years. The two " eliminated" cases, numbers eleven and twenty-three in this group, are alive, after three, and one and a half years, respectively.

Table I shows results from the present series, expressed as percentages and compares these with Callender and Wilder.

In both series the results are practically the same in Group 2, and exactly equal in Group 3, the divergence in Group 1, being due to the very small number of cases investigated and the fact that one of the survivors' of the present series, number nine, died shortly after five years, and that the other, number fourteen, had an extraordinarily well formed reticulin capsule to the growth. This may, but I have no proof of it, have been the deciding factor in his survival, although no reticulin was present actually in the growth.

Table II shows the individual cases set out separately and numbered :-

Note: In Group 2, “+ +" indicates a predominance of areas with reticulin fibres, in contrast to " +", indicating areas with and without fibres in approximately equal proportions.

In view of the small number of cases investigated, the prognostic influence of reticulin content cannot, I think, be definitely established, especially in view of the fact that no definite conclusions can be drawn where cases are not followed for a considerably longer period than five years. 
TABLE I

Table shewing results from the present series compared with those obtained by Callender and Wilder

\begin{tabular}{|c|c|c|c|c|c|c|c|c|c|c|}
\hline \multicolumn{3}{|c|}{ Total } & \multicolumn{4}{|c|}{ Alive after five years } & \multicolumn{4}{|c|}{ Died within five years } \\
\hline Group & c. \& w. & $\begin{array}{l}\text { Present } \\
\text { Series }\end{array}$ & C. \& W. & $\begin{array}{l}\text { Present } \\
\text { Series }\end{array}$ & $\begin{array}{l}\text { C. \& W. W. } \\
\text { Per cent. }\end{array}$ & $\begin{array}{l}\text { Present } \\
\text { Series } \\
\text { Per cent }\end{array}$ & C. \& W & $\mid \begin{array}{l}\text { Present } \\
\text { Series }\end{array}$ & $\begin{array}{l}C \& W \\
\text { Per cent }\end{array}$ & $\begin{array}{c}\text { Present } \\
\text { Series } \\
\text { Per cent. }\end{array}$ \\
\hline 1 & 3 & 4 & - & 2 & - & 50 & 3 & 2 & 100 & 50 \\
\hline 2 & 38 & 8 & 12 & 3 & $31 \%$ & 37.5 & 20 & 5 & $68^{\circ} 4$ & $62^{\circ} 5$ \\
\hline 3 & 5 & 3 & 5 & 3 & 100 & 100 & - & 一 & - & - \\
\hline
\end{tabular}

TABLE II

Cases now dead

\begin{tabular}{|c|c|c|c|c|c|c|}
\hline $\begin{array}{l}\text { No. of } \\
\text { Case }\end{array}$ & $\begin{array}{c}\text { Group } \\
\text { One }\end{array}$ & $\begin{array}{c}\text { Group } \\
\text { Two }\end{array}$ & $\begin{array}{l}\text { Group } \\
\text { Three }\end{array}$ & $\begin{array}{c}\text { Extra-ocular } \\
\text { extension }\end{array}$ & $\begin{array}{l}\text { Cause of } \\
\text { Death }\end{array}$ & $\begin{array}{l}\text { Duration of life } \\
\text { after operation }\end{array}$ \\
\hline 1 & .. & ++ & .. & $\cdots$ & $\begin{array}{c}\text { Metastas } \in \text { S } \\
\text { in Liver }\end{array}$ & 57 \\
\hline 2 & ... & + & $\ldots$ & + & ditto & $2 \cdot 2$ \\
\hline 3 & ... & + & $\ldots$ & . $\quad \ldots$ & ditto & $3^{\circ} 0$ \\
\hline 4 & .. & $+t$ & $\therefore$ & + & ditto & $24 \ldots$ \\
\hline 5 & ... & + & ... & $\ldots$ & ditto & 27 \\
\hline 6 & ... & + & $\cdots$ & ... & ditto & $3 \cdot 3$ \\
\hline 7 & + & $\ldots$ & $\ldots$ & $\ldots$ & ditto & $2 \% 6$ \\
\hline 8 & + & ... & ... & $\cdot \ldots$ & ditto & $0 \% 6$ \\
\hline 9 & + & $\therefore$ & $\cdots$ & ... & ditto & $5^{\circ} 0$ \\
\hline
\end{tabular}

It will be noticed from the table showing "Survival and Mortality Rates-all cases," elsewhere in this paper, that 11 per cent. die from sarcoma after five years. 
TABLE II

Cases now Alive

\begin{tabular}{|c|c|c|c|c|c|}
\hline $\begin{array}{l}\text { No. of } \\
\text { Case }\end{array}$ & $\begin{array}{c}\text { Group } \\
\text { One }\end{array}$ & $\begin{array}{c}\text { Group } \\
\text { Two }\end{array}$ & $\begin{array}{l}\text { Group } \\
\text { Three }\end{array}$ & $\begin{array}{l}\text { Extra-ocular } \\
\text { extension }\end{array}$ & $\begin{array}{c}\text { Alive after } \\
\text { operation }\end{array}$ \\
\hline 10 & $\ldots$ & $\ldots$ & + & $\ldots$ & $5^{\circ} 0$ \\
\hline 11 & $\ldots$ & $\ldots$ & + & $\ldots$ & $3^{\circ} 0$ \\
\hline 12 & $\ldots$ & $\ldots$ & + & $\ldots$ & $5^{\circ} 0$ \\
\hline 13 & $\ldots$ & $\ldots$ & $\cdot+$ & + & $5^{\circ} 0$ \\
\hline 14 & + & $\ldots$ & $\ldots$ & $\ldots$ & $8^{\circ} 0$ \\
\hline 15 & $\ldots$ & + & ... & $\ldots$ & $7 \cdot 6$ \\
\hline 1,6 & $\ldots$ & + & $\because$ & $\ldots$ & $5^{\circ} 0$ \\
\hline 17 & + & $\ldots$ & $\ldots$ & ... & 10 \\
\hline 18 & $\ldots$ & + & $\ldots$ & $\therefore$ & $0^{\circ} 9$ \\
\hline 19 & + & ... & $\ldots$ & $\ldots$ & $0^{\circ} 6$ \\
\hline 20 & $\ldots$ & + & $\ldots$ & $\ldots$ & 26 \\
\hline 21 & $\ldots$ & $\dot{+}+$ & $\ldots$ & $\ldots$ & 10 \\
\hline 22 & $\ldots$ & ++ & $\ldots$ & $\ldots$ & $1^{\circ} 6$ \\
\hline 23 & $\ldots$ & $\ldots$ & + & $\ldots$ & $1 \% 8$ \\
\hline 24 & $\ldots$ & + & $\ldots$ & $\cdots$ & 11 \\
\hline
\end{tabular}

It does, however, appear that growths that fall into Group 3, and possibly growths in which reticulin is absent, or sparse within the growth, but exhibit a closed capsule of reticulin, are of more favourable prognosis than those in other groups.

\section{BIBLIOGRAPHY}

Callender, G. R. and Wilder, H. C.-Amer. Jl. of Cancer., Vol. XXV, 11, p. 251. 1935 . 
RETICULIN-GROUP I (Absence of Reticulin)

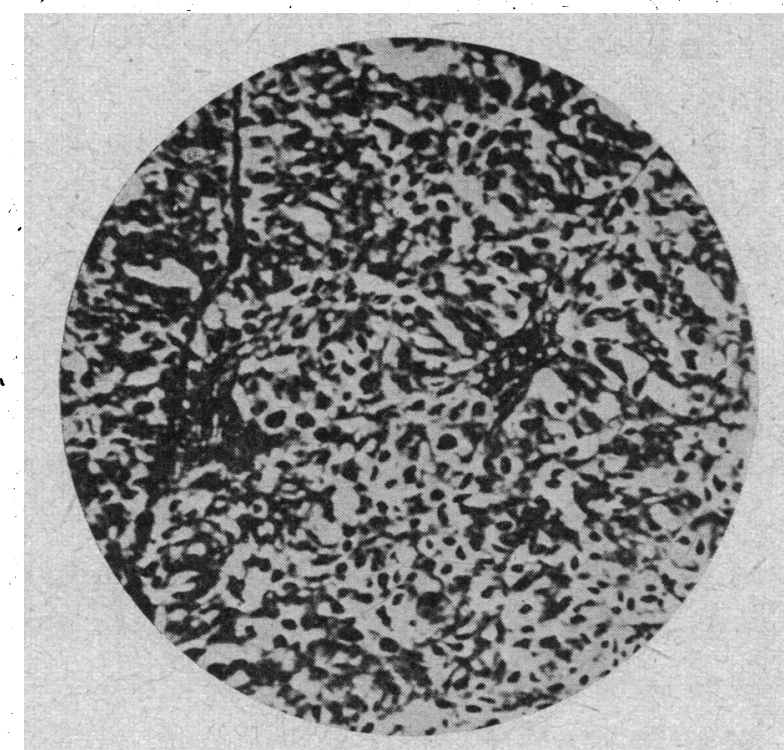

- CASE 14.-Microphotograph 1.

Illustrates section treated by silver impregnation method, no reticulin fibres being present.

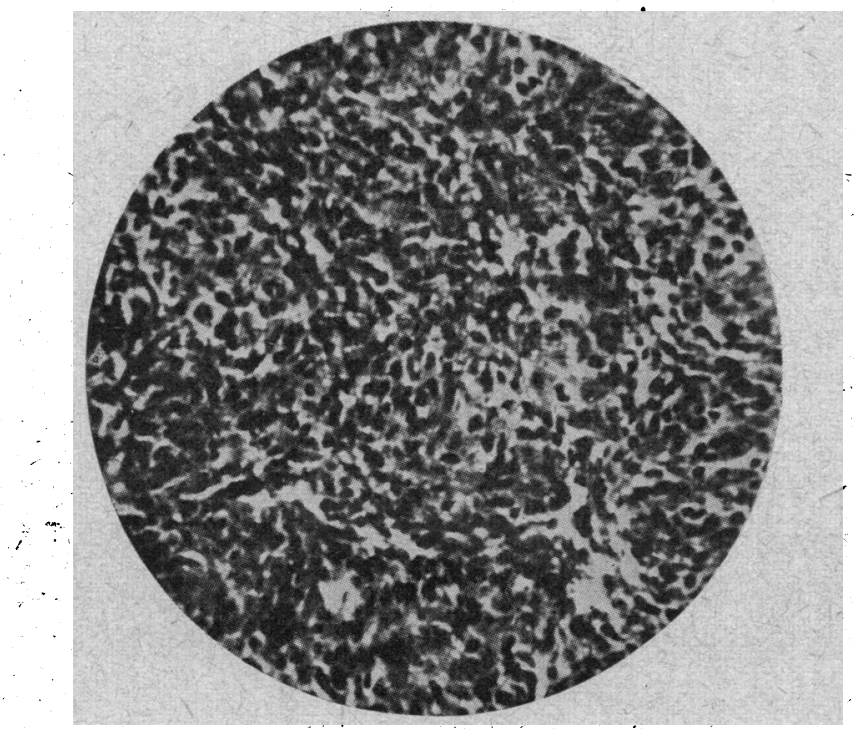

CASE 14:-Microphotograph 2.

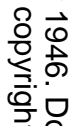

位

วิ

ฉั

즘

을

$$
\text { 三 }
$$

훔

응

믐

ช

윽

금

N

กิ

N

ฮ

这

Illustrates similar section stained with baematoxylin and eosin. 


\section{GROUP II-RETICULIN-Case 21}

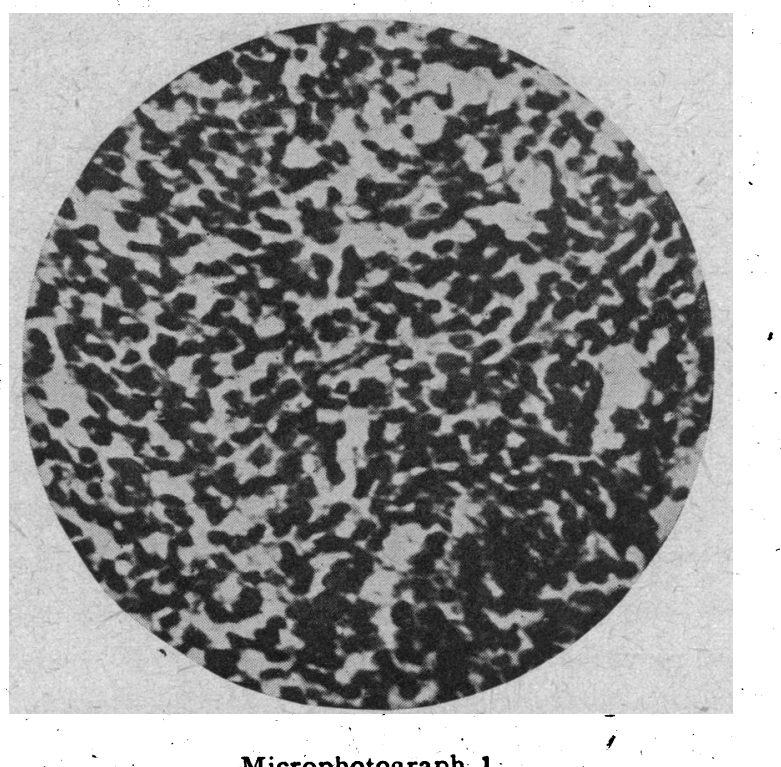

Microphotograph 1:

Haematoxylin and eosin section of a heavily pigmented choroidal sarcoma.

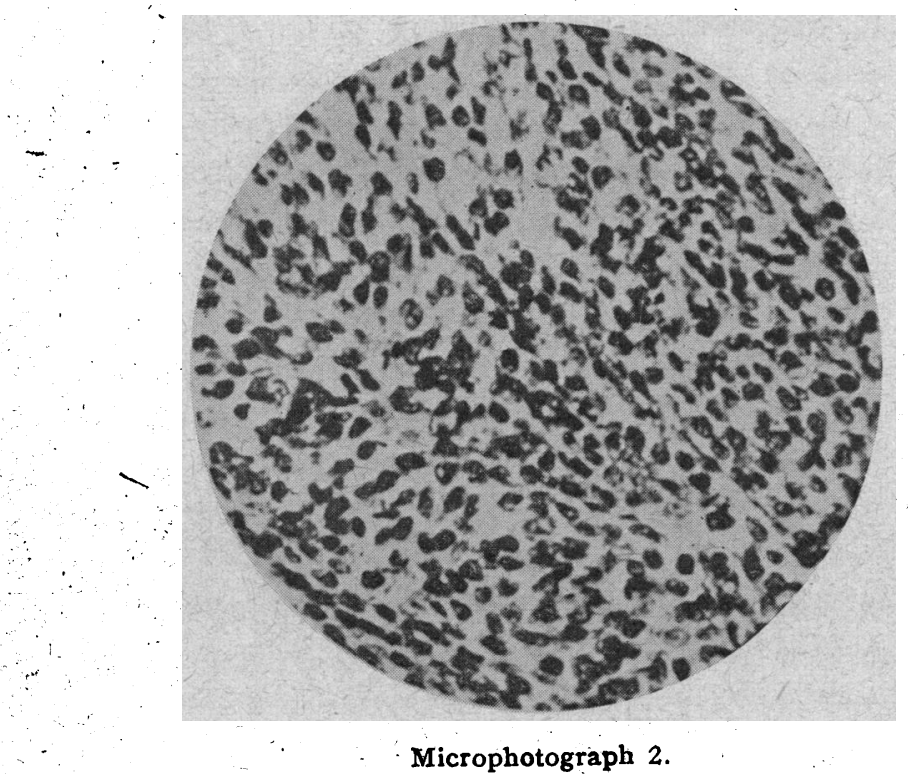

Similar section of growth stained by silver impregnation showing absence of reticulin fibres. 


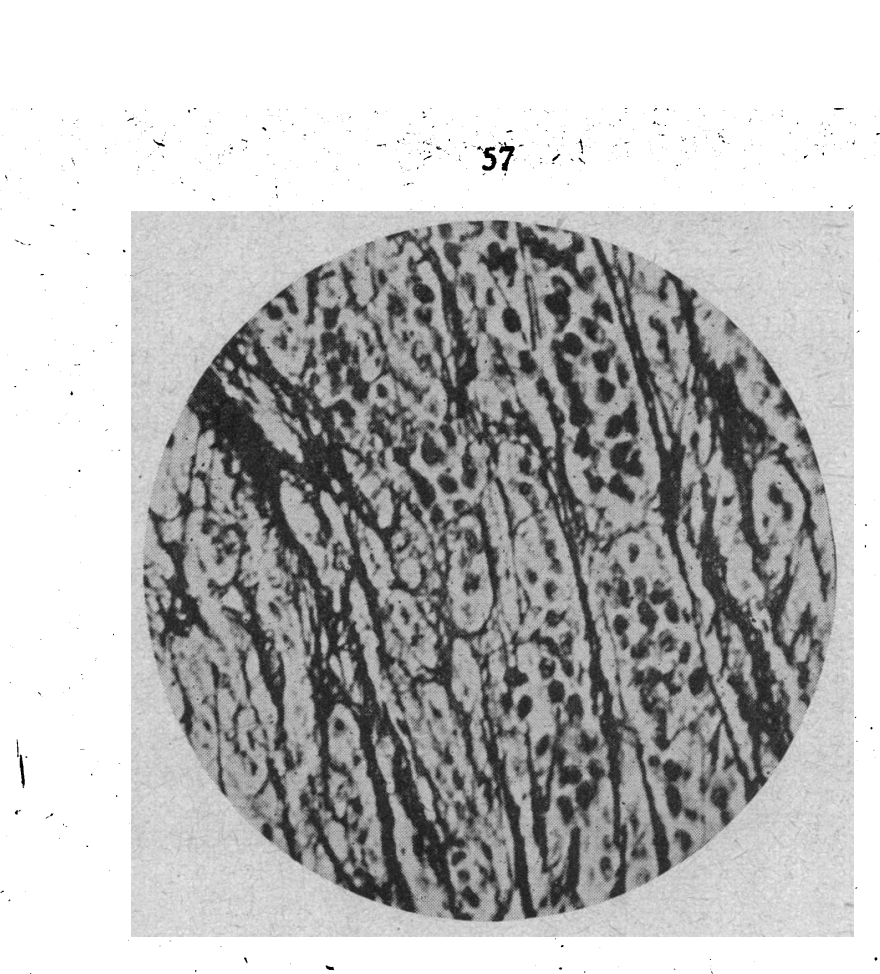

Microphotograph 3.,

Section of same growth showing reticulin fibres.

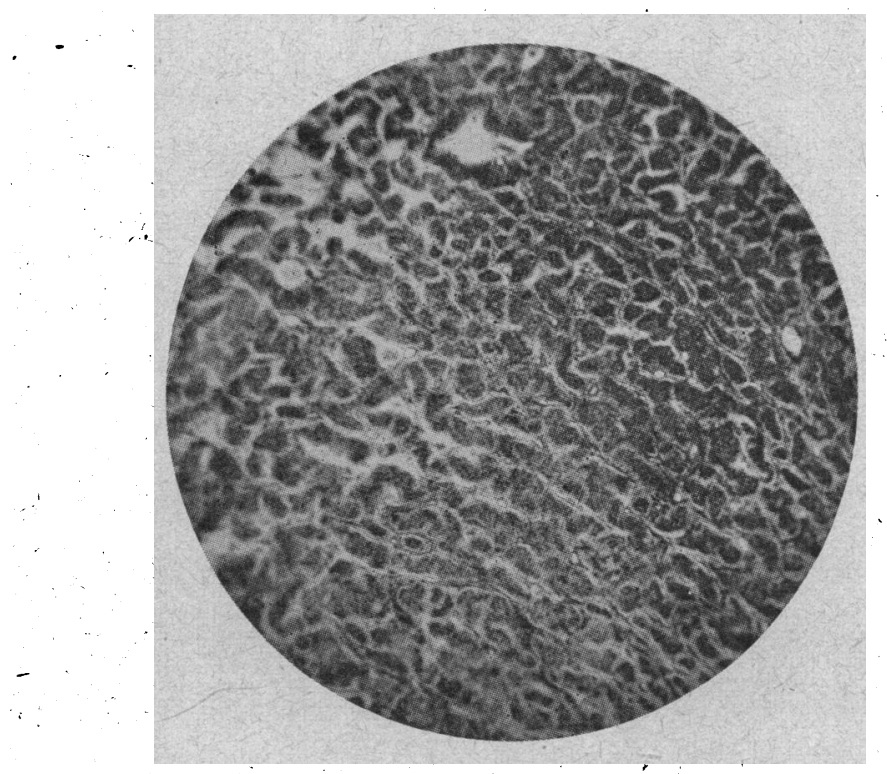

Microphotograph 4.

Low power microphotograph of growth treated with silver impregnation method showing reticulin fibres. 


\section{RETICULIN-GROUP III}

(Reticulin present throughout the neoplasm)

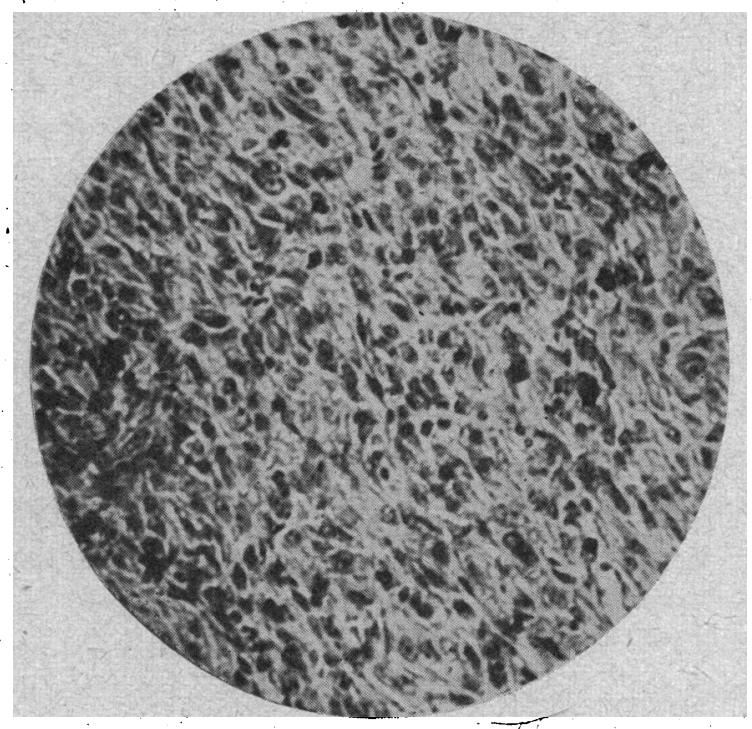

CASE 2.-Microphotograph 1.

Hæmatoxylin and eosin section of spindle celled choroidal sarcoma.

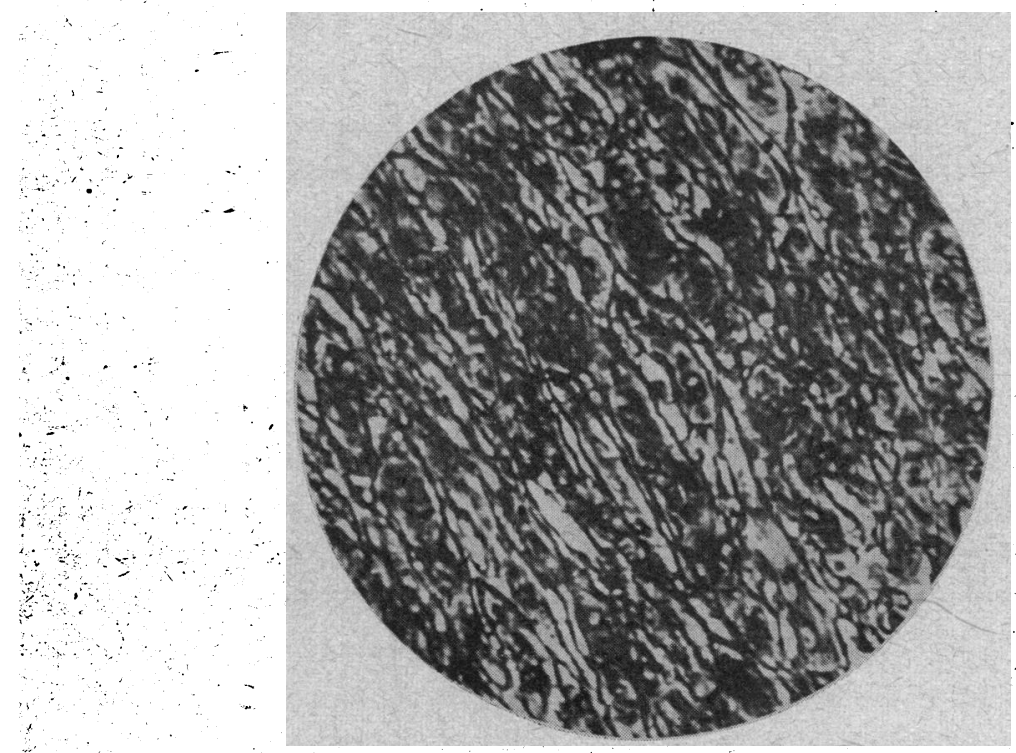

CASE 2.-Microphotograph. 2.

을

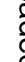

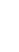

(1)

垔

$\stackrel{0}{2}$

定

ํㅗㅇ

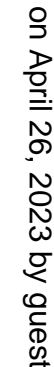

Similar section treated by silver impregnation showing reticulin fibres.

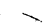

